\title{
PENGGUNAAN BUKU KOMIK KARYA GURU UNTUK MENINGKATKAN KEMAMPUAN MENULIS SISWA KELAS 3 SDN 2 DUWET KECAMATAN PANARUKAN
}

\author{
Aenor Rofek ${ }^{1)}$ \\ 1) Universitas Abdurachman Saleh Situbondo \\ gonzalesrofik99@gmail.com
}

\begin{abstract}
ABSTRAK: Peningkatan pembelajaran menulis pada anak-anak yang masih berpikiran seperti itu sangatlah penting. Sebelumnya pada saat prasiklus jumlah siswa yang mengalami ketuntasan belajar hanya 6 siswa (30\%), karena pada tahap ini guru belum memberikan tindakan pada pembelajaran menulis cerita. Setelah diberi tindakan yaitu dengan penggunaan media buku komik dalam pembelajaran menulis cerita siswa yang mengalami ketuntasan belajar meningkat menjadi 15 siswa (85\%). Untuk memperbaiki pembelajaran pada siklus I maka peneliti melaksanakan siklus II, dimana kekurangankekurangan yang terjadi pada siklus I disempurnakan dan diperbaiki pada siklus II. Setelah diadakan perbaikan maka pada siklus II buku komik karya guru yang digunakan ceritanya tidak terlalu panjang dan kata-katanya mudah dimengerti oleh siswa sehingga siswa dapat menceritakan kembali isi cerita secara runtut. Pada siklus II setelah diberi tindakan perbaikan maka kemampuan menulis cerita siswa pada siklus II meningkat menjadi 16 siswa (90\%). Pada siklus II ini ketuntasan belajar siswa sudah mencapai kriteria ketuntasan minimal yang telah ditentukan.
\end{abstract}

Kata kunci : Komik Karya Guru, PTK, dan Menulis.

ABSTRACT: Improving learning to write to children who still think like that is very important. Previously during the pre-cycle the number of students who experienced mastery learning was only 6 students (30\%), because at this stage the teacher had not yet given action on learning to write stories. After being given an action, namely the use of comic book media in learning to write stories, students who experienced mastery learning increased to 15 students (85\%). To improve learning in cycle I, the researchers carried out cycle II, where deficiencies that occurred in cycle I were refined and corrected in cycle II. After the improvement is made, in the second cycle of the comic book the teacher uses, the story is not too long and the words are easily understood by students so students can retell the contents of the story coherently. In cycle II after being given corrective action, the ability to write stories to students in cycle II increased to 16 students (90\%). In this second cycle students' learning completeness has reached the specified minimum completeness criteria

Keywords: Teacher's Comics, CAR and Writing.

\section{PENDAHULUAN}

Menulis merupakan suatu keterampilan yang tidak dapat dipisahkan dari proses belajar mengajar yang berlangsung di sekolah. Menulis termasuk ke dalam tataran keterampilan berbahasa yang paling sulit karena untuk menghasilkan sebuah tulisan yang baik diperlukan penguasaan terhadap tiga keterampilan berbahasa lainnya. Tarigan 
(2008: 49) mengatakan bahwa menulis memiliki nilai tinggi dan bermakna abadi, namun dalam masyarakat masih terdapat dilema bahwa menulis itu menakutkan, bakat, seni, profesi, dapat dipelajari, dan mendidik. Beragamnya pendapat yang berkembang di masyarakat tentang menulis justru malah membuat sebagian orang berpikir dua kali untuk dapat menguasai atau menekuni keterampilan berbahasa yang satu ini.

Sebagai suatu keterampilan, menulis memang harus melalui proses belajar dan berlatih. Semakin sering belajar dan berlatih, tentu semakin cepat terampil. Seseorang yang sudah biasa menuliskan sebuah ide, gagasan, pendapat, atau perasaannya, maka dia tidak akan mengalami kesulitan berarti ketika harus menulis. Berbeda halnya jika seseorang jarang atau bahkan sama sekali tidak pernah membuat sebuah karya tulisan. Tentunya orang tersebut akan mengalami banyak kesulitan ketika diminta menuliskan sesuatu.

Selain itu kemampuan berpikir juga akan mempengaruhi kemampuan seseorang untuk menuliskan sesuatu, misalnya: karya ilmiah, cerita pendek, atau puisi. Kemampuan berpikir siswa SD (Sekolah Dasar) akan berbeda dengan cara berpikir siswa Sekolah Menengah Atas (SMA). Pada siswa SD kemampuan berpikir mereka dapat dikatakan masih bersifat kekanak-kanakan dan kemampuan berpikir yang bersifat imajinatif belum berkembang dengan baik. Menurut Nurgiyantoro (2009: 18) peningkatan pembelajaran menulis pada anak-anak yang masih berpikiran seperti itu sangatlah penting. Lebih lanjut, dijelaskan bahwa dalam pembelajaran menulis untuk anak-anak masih ada berbagai kelemahan. Kelemahan tersebut berakibat antara lain: siswa mengalami kesulitan dalam menulis cerita, nilai pelajaran yang berkaitan dengan menulis cerita tidak memuaskan, tidak ada ketertarikan siswa dalam pelajaran Bahasa Indonesia khususnya menulis cerita, dan kurangnya pemahaman siswa dalam pembelajaran menulis cerita.

Demikian pula yang terjadi pada siswa kelas 3 SD Negeri 2 Duwet Kec. Panarukan Kabupaten Situbondo. Berdasarkan hasil wawancara awal di SDN 2 Duwet, diketahui bahwa terdapat permasalahan dalam pembelajaran menulis cerita di kelas 3 . Permasalahan-permasalahan tersebut adalah siswa masih kesulitan dalam menentukan tema cerita, siswa kurang mampu dalam mengembangkan jalan cerita sehingga jalan cerita tidak runtut. Hal ini berdampak pada rendahnya nilai mata pelajaran bahasa indonesia khususnya menulis cerita.

Faktor utama penyebab rendahnya kemampuan menulis cerita pada siswa yaitu minimnya penggunaan media dalam pembelajaran, hal ini menjadi salah satu faktor penyebab masih rendahnya kemampuan menulis cerita pada siswa. Selama ini siswa merasa bosan dan tidak tertarik untuk mengikuti kegiatan pembelajaran menulis cerita. Selain kedua faktor tersebut, selama kegiatan observasi yang peneliti lakukan terlihat pula bahwa guru cenderung hanya menggunakan metode ceramah dan pemberian tugas menulis cerita pada siswa, tanpa memberikan media yang sesuai. Hal ini semakin membuat ide siswa tidak dapat berkembang dengan baik. Oleh karena itu, perlu dicari 
jalan keluar untuk memecahkan beberapa permasalahan tersebut. Salah satu jalan keluarnya yaitu dengan penggunaan media pembelajaran yang dapat merangsang ide dan kreativitas siswa serta mampu membuat siswa lebih aktif lagi selama proses pembelajaran berlangsung di samping guru juga harus mengubah cara mengajarnya. Guru menyadari betul bahwa penggunaan media akan membantu siswa menemukan ide atau gagasan. Salah satu media yang bisa digunakan dalam pembelajaran membaca cerita adalah buku komik.

Buku komik sangat bagus diterapkan pada pembelajaran menulis cerita karena buku komik memuat cerita yang berisi tentang rangkaian kejadian yang ada dalam cerita. Seorang anak yang tengah membaca komik tidak hanya melihat gambaran visual atau teksnya saja, tetapi juga memperhatikan detail gambarnya. Misalnya bagaimana karakter, mimik dari para tokohnya dan jalan ceritanya. Buku komik yang digunakan adalah buku komik ciptaan dari guru-guru di SDN 2 Duwet.

Buku komik ciptaan guru di SD 2 Duwet ini memiliki kelebihan yaitu, cerita yang disampaikan sesuai dengan realitas di SDN 2 Duwet itu sendiri, sesuai dengan topik, karakter cerita maupun ciri khas dari Guru di SDN 2 Duwet.

Hal-hal tersebut dapat memperkaya kecerdasan visual, mengembangkan daya imajinasi anak, dan membantu siswa untuk memahami isi cerita secara menyeluruh. Selain itu, dengan adanya gambar-gambar yang menarik dapat membuat siswa lebih bersemangat mengikuti kegiatan pembelajaran. Buku komik merupakan dunia yang lekat dengan anak karena keunggulan visualnya serta tokoh-tokohnya yang cenderung menghibur dapat menumbuhkan minat membaca pada anak (Franz, 1983:69).

Berdasarkan permasalahan yang ditemukan di kelas 3 SDN 2 Duwet, peneliti tertarik untuk melakukan penelitian dengan judul "Penggunaan Buku Komik Karya Guru Untuk Meningkatkan Kemampuan Menulis Siswa Kelas 3 SD Negeri 2 Duwet Kecamatan Panarukan Semester Ganjil Tahun Ajaran 2018/2019”.

Berdasarkan latar belakang tersebut, rumusan masalah dalam penelitian ini adalah sebagai berikut.

1. Bagaimanakah Penerapan Buku Komik Karya Guru Untuk Meningkatkan Kemampuan Menulis Siswa Kelas 3 SD Negeri 2 Duwet Kecamatan Panarukan Semester Ganjil Tahun Ajaran 2018/2019?

2. Bagaimanakah hasil belajar bahasa Indonesia materi Kemampuan Menulis Siswa Kelas 3 SD Negeri 2 Duwet Kecamatan Panarukan Semester Ganjil Tahun Ajaran 2018/2019?

\section{METODE PENELITIAN}

\section{Tempat dan Waktu Penelitian}

Penelitian ini dilaksanakan di SD Negeri 2 Duwet Kec. Panarukan, Kabupaten Situbondo pada Semester ganjil Tahun pelajaran 2018/ 2019. 


\section{Rancangan Penelitian}

Rancangan penelitian yang digunakan dalam penelitian ini adalah rancangan Penelitian Tindakan Kelas (PTK). Rancangan ini dinilai sesuai dengan fokus dan tujuan penelitian, yaitu upaya meningkatkan kemampuan menulis cerita siswa kelas 3 SD Negeri 2 DuwetKec. Panarukan.

\section{Tahap Penelitian}

Pada tahap penelitian ini, adapun langkah-langkah yang akan dilakukan sebagai berikut.

\section{Prasiklus}

Pada tahap prasiklus ini dilakukan penelitian awal untuk mengetahui situasi yang sebenarnya, seberapa besar hasil belajar siswa dalam menulis cerita dengan model pembelajaran yang biasa digunakan oleh guru. Pada pengamatan awal, dilakukan observasi terhadap proses pembelajaran bahasa Indonesia di kelas 3 SDN 2 Duwet Kec. Panarukan. Permasalahan yang ditemukan menuntut disusunnya rencana berupa tindakan untuk melakukan perbaikan, peningkatan atau perubahan kearah yang lebih baik dari proses pembelajaran. Tindakan yang dilakukan untuk memecahkan masalah tersebut adalah dengan menerapkan pembelajaran menulis cerita melalui penggunaan buku buku komik, Penerapan tersebut dilakukan pada siklus I.

\section{Siklus I}

Berdasarkan pengamatan awal pada tahap prasiklus, hasil yang didapat peneliti adalah rendahnya kemampuan siswa kelas 3 SD Negeri 2 Duwet Kec. Panarukan dalam menulis cerita sehingga peneliti menerapkan siklus I. Penerapan siklus I ini bertujuan untuk meningkatkan hasil belajar siswa dalam menulis cerita melalui penggunaan buku komik.Adapun langkah-langkah yang akan dilakukan peneliti pada siklus ini adalah sebagai berikut.

\section{a. Perencanaan}

Dalam penelitian tindakan kelas ini peneliti bertindak sebagai observer terhadap guru kelas 3 dalam melaksanakan pembelajaran Bahasa Indonesia. Adapun persiapan yang dilakukan meliputi kegiatan sebagai berikut.

1) Diskusi dengan guru kelas 3 tentang permasalahan yang akan diteliti dan tindakan yang akan dilaksanakan.

2) Mendiagnosis kesulitan siswa dalam menulis cerita dengan cara menganalisis data hasil belajar siswa pada tahap prasiklus atau penelitian awal.

3) Menyusun perangkat pembelajaran, yang meliputi: rencana pembelajaran, silabus, dan sistem penilaian.

4) Pembuatan instrumen penelitian untuk persiapan penelitian tindakan kelas. Instrumen penelitian yang dibuat meliputi: instrumen pengumpul data, yang terdiri dari lembar observasi terhadap siswa dan guru dan lembar tes untuk siswa.

5) Mempersiapkan dan membuat alat evaluasi.

b. Pelaksanaan Tindakan

Setelah prasiklus dilakukan, dimulailah siklus pertama, dalam siklus I peneliti berusaha memperbaiki dan meningkatkan hasil belajar siswa yang telah dilakukan pada prasiklus. Tindakan tersebut akan dilakukan dengan menerapkan penggunaan buku komik dalam menulis cerita. 
Peneliti dalam hal ini berperan sebagai observer yang akan berkolaborasi dengan guru kelas 3. Peneliti akan menjelaskan hal-hal yang perlu diperhatikan dalam proses pembelajaran Bahasa Indonesia dengan menerapkan penggunaan buku komik, sedangkan guru sebagai pihak yang melakukan tindakan.

Pelaksanaan tindakan dapat digambarkan sebagai berikut.

1) Kegiatan Awal

a) Guru membuka pelajaran dengan mengucapkan salam.

b) Guru mengabsen siswa.

c) Guru menyampaikan tujuan pembelajaran.

d) Guru memberikan motivasi kepada siswa dengan menyampaikan manfaat yang dapat diperoleh jika menguasai materi tentang menulis cerita.

e) Guru memberikan apersepsi yang berhubungan dengan materi yang akan disampaikan.

2) Kegiatan Inti

a) Guru menjelaskan tentang materi menulis cerita pada siswa.

b) Siswa mendengarkan penjelasan guru tentang materi menulis cerita.

c) Guru menyampaikan tentang hal-hal yang harus diperhatikan dalam menulis cerita.

d) Guru melakukan tanya jawab dengan siswa tentang materi yang baru saja dijelaskan.

e) Siswa menjawab pertanyaan guru tentang hal-hal yang harus diperhatikan dalam menulis cerita.

f) Siswa mendengarkan penjelasan guru tentang pembagian kelompok. Siswa dibagi dalam 5 kelompok.

g) Siswa membentuk kelompok sesuai ketentuan guru dengan jumlah anggota \pm 4 orang.

h) Guru memberikan teks cerita berbentuk buku komik yang berjudul "bermain korek api" kepada siswa.

i) Siswa membaca cerita dengan memahami isi cerita secara menyeluruh.

j) Guru memberikan lembar soal yang berisi tentang hal-hal yang berkaitan dengan isi teks cerita

k) Guru menjelaskan secara klasikal mengenai cara-cara menceritakan kembali isi cerita dengan kalimat sendiri secara runtut pada masing-masing kelompok.

1) Siswa mendengarkan penjelasan guru mengenai cara-cara menceritakan kembali isi cerita pada masing-masing kelompok.

m) Siswa secara individu menceritakan kembali isi cerita dengan kalimat sendiri secara runtut pada buku tulisnya.

n) Masing-masing wakil terbaik dari setiap kelompok menceritakan kembali isi cerita di depan kelas.

o) Guru melakukan tanya jawab dengan siswa tentang materi menulis cerita yang baru dipelajari. 
3) Kegiatan Akhir

a) Guru meminta siswa mengumpulkan hasil pekerjaannya.

b) Membimbing siswa menyimpulkan materi tentang menulis cerita yang baru saja dipelajari.

c) Guru meminta siswa merefleksi pembelajaran.

d) Guru menutup pelajaran dengan mengucapkan salam.

c. Observasi

Observer melakukan pengamatan cermat untuk mengetahui keefektifan penerapan pembelajaran menulis cerita melalui penggunaan buku komik. Observasi ini dilakukan pada guru dan siswa. Observasi terhadap guru berkaitan dengan kesesuaian antara perencanaan pembelajaran dan proses pembelajaran yang dilakukan oleh peneliti sebagai pelaku tindakan. Observasi terhadap siswa, berkaitan dengan perilaku siswa dalam mengikuti proses pembelajaran.

d. Refleksi

Refleksi merupakan upaya untuk mengkaji apa dan bagaimana dampak dari suatu tindakan kelas. Refleksi dilakukan dengan cara mengolah data, menganalisis, menjelaskan dan menyimpulkan bagaimanakah perubahan aktivitas dan hasil belajar siswa setelah dilaksanakan kegiatan belajar mengajar Bahasa Indonesiamenulis cerita dengan menggunakan media buku komik.Hasil analisis data yang dilaksanakan dalam tahap ini dipergunakan sebagai acuan untuk merencanakan siklus berikutnya yaitu siklus II.

Siklus II

a. Perencanaan

Tahap ini merupakan rencana perbaikan dari siklus I. Berdasarkan refleksi yang telah dilakukan pada siklus I, diperoleh data mengenai kekurangan-kekurangan yang terjadi pada siklus I dan menentukan tindakan berikutnya dengan tujuan agar hasil tindakan yang dicapai lebih optimal. Kegiatan yang dialakukan antara lain.

b. Pelaksanaa Tindakan

Pelaksanaan tindakan pada siklus II sama dengan pelaksanaan siklus I. Hanya saja ada perubahan dan penyempurnaan atas kegiatan siklus I yang dilaksanakan pada siklus II.

c. Observasi

Pada tahap ini, peneliti dibantu dengan observer melakukan observasi dengan lebih cermat terhadap aspek-aspek yang belum bisa diraih dalam observasi pada siklus I, sehingga dapat diperoleh hasil yang lebih sempurna.

d. Refleksi

Pada siklus II ini refleksi dilakukan sebagai upaya untuk mengkaji apa dan bagaimana dampak dari suatu tindakan kelas. Refleksi pada tindakan ini adalah guru beserta observer menganalis hasil belajar yang diperoleh siswa selama proses pembelajaran. 


\section{Data dan Sumber Data}

Terdapat dua data dalam penelitian ini yaitu: (1) data berupa perilaku siswa dan guru kelas 3SD Negeri 2 DuwetKec. PanarukanKabupaten Situbondo sebagai pelaku tindakan dalam pembelajaran menulis cerita baik pada siklus I dan selanjutnya melalui penggunaan buku komik yang didapatkan dari hasil observasi dan wawancara, (2) data berupa hasil belajar siswa dalam pembelajaran menulis cerita melalui penggunaan buku komik didapatkan dari hasil tes. Sumber data dalam penelitian ini adalah seluruh siswa dan guru kelas 3 SD Negeri 2 DuwetKec. Panarukan Kabupaten Situbondo tahun pelajaran 2018/2019 Jumlah siswa di kelas ini berjumlah 20 siswa dengan kemampuan yang heterogen.

\section{Teknik Pengumpulan Data}

Teknik pengumpulan data dalam penelitian ini berfungsi untuk mendapatkan data yang valid sebagai penunjang keberhasilan dalam penelitian. Dalam penelitian ini teknik pengumpulan data yang digunakan adalah dengan, observasi, tes, wawancara dan dokumentasi.

a. Observasi

Pada penelitian ini digunakan observasi langsung yang dilaksanakan dalam proses belajar mengajar. Observasi ini dilakukan terhadap aktivitas guru dan siswa pada waktu pembelajaran sebelum dan sesudah menerapkan penggunaan buku komik dengan menggunakan lembar observasi yang telah disiapkan. Observasi dilakukan oleh 3 orang observer yang terdiri dari guru kelas dan 2 rekan peneliti.

b. Tes

Tes ini digunakan untuk memperkuat data observasi dan untuk mengukur sejauh mana siswa dapat memahami tentang materi menulis cerita yang telah disampaikan oleh guru. Siswa ditugaskan untuk membaca cerita pada buku komik, kemudian siswa diminta untuk menceritakan kembali isi cerita menggunakan kata-katanya sendirisecara runtut.

c. Wawancara

Data yang diperoleh dari metode wawancara akan digunakan untuk melengkapi dan mendukung data utama dalam penelitian. Pada penelitian ini wawancara dilakukakn pada siswa dan guru sebelum penerapan dan sesudah penerapan pembelajaran menulis cerita melalui penggunaan buku komik karya guru.

d. Dokumentasi

Dokumentasi digunakan untuk mengumpulkan data dengan cara melihat dan mencatat kembali data yang ada dan yang diperlukan dalam penelitian. Data ini digunakan sebagai barang bukti yang berbentuk tulisan maupun cetak dan mempunyai hubungan dengan permasalahan yang diteliti. Dokumentasi dalam penelitian ini berupa hasil wawancara, lembar pengamatan dari observer, daftar nilai siswa, dan foto selama kegiatan pembelajaran.

\section{Analisis Data}

Analisis data yang digunakan dalam penelitian ini adalah statistik deskriptif kualitatif dan deskriptif kuantitatif. Analisis data kualitatif diperoleh dari hasil observasi dan wawancara. Analisis data kuantitatif diperoleh dari hasil tes kemampuan menulis masing-masing siswa. Analisis data merupakan penentu untuk menyusun dan mengolah 
data yang terkumpul, sehingga manghasilkan suatu kesimpulan yang dapat dipertanggungjawabkan kebenarannya.

Tahap-tahap yang dilakukan dalam menganalisis data dalam penelitian ini adalah sebagai berikut:

a. Klasifikasi data

Klasifikasi data dilakukan dengan cara memilah-milah data yang telah terkumpul. Data yang terkumpul diklasifikasikan sesuai dengan kelompok tertentu. Tujuannya dapat memudahkan dalam penyajian dan penyimpulan. Dengan demikian, hasil penelitian diharapkan dapat memberikan gambaran yang terjadi saat tindakan.

\section{b. Penyajian Data}

Penyajian data berupa deskriptif dari hasil pengamatan dan wawancara. Sedangkan data kuantitatif diperoleh dari hasil tes kemampuan siswa dalam menulis karangan ketika menggunakan model kalimat konsep dengan media komik pendidikan.

\section{HASIL DAN PEMBAHASAN}

\section{Hasil Penelitian}

Deskripsi Kondisi Pada Pembelajaran Menulis Cerita buku komik karya guru Prasiklus.

Pembelajaran menulis cerita buku komik karya guru sebelum diterapkan penggunaan buku komik buku komik karya guru dilakukan oleh guru kelas 3 SDN 2 Duwet dengan menggunakan metode dan media yang biasa digunakan guru yaitu buku paket. Pembelajaran diikuti oleh seluruh siswa kelas 3 sebanyak 18 siswa.

Pada tahap ini, prosedur pembelajaran dimulai dengan membuka pelajaran dan dilanjutkan penjelasan guru mengenai hal-hal yang harus diperhatikan dalam menulis cerita. Selanjutnya, guru menyuruh siswa menulis cerita. Pada saat pengerjaan, siswa tidak bersemangat, bercanda dengan teman lain, bahkan ada siswa yang diam. Interaksi antara siswa dengan guru dan siswa dengan siswa terlihat kurang terjalin, sehingga hanya beberapa siswa saja yang mengerjakan tugas dari guru. Setelah mengerjakan tugas, siswa diminta mengumpulkan hasil karangannya. Kemudian pembelajaran diakhiri. Kegiatan pembelajaran ini membuat siswa bosan dan kurang berminat dalam pembelajaran. Sehingga mengakibatkan hasil belajar yang diperoleh siswa kurang memuaskan.

Kemampuan menulis cerita siswa kelas 3 SDN 2 Duwet secara klasikal pada prasiklus yaitu 30\% atau hanya terdapat 6 orang siswa yang tuntas, sedangkan siswa yang tidak tuntas berjumlah 12 atau 70\%. Dari presentasi tersebut menunjukkan bahwa hasil belajar yang dicapai masih rendah.

\section{Penerapan Pembelajaran Menulis Cerita Melalui Penggunaan Buku Komik karya guru.}

Proses penggunaan buku komik untuk meningkatkan kemampuan menulis cerita siswa kelas 3 SDN 2 Duwet dilakukan dengan dua siklus. a. Siklus I

Kegiatan yang dilakukan pada siklus I merupakan usaha perbaikan untuk meningkatkan hasil belajar menulis cerita pada siswa kelas 3 SDN 2 Duwet.

1) Perencanaan 
Pada tahap ini yang dilakukan peneliti adalah :

a) Menyusun Rencana Pelaksanaan Pembelajaran (RPP) Siklus I.

b) Mempersiapkan media berupa buku komik karya guru.

c) Menyusun lembar observasi aktivitas guru.

d) Menyusun pedoman penilaian Tes.

2) Pelaksanaan

Prosedur pembelajaran menulis cerita melalui penggunaan buku komik pada siklus ini dapat diuraikan sebagai berikut.

a) Kegiatan Awal

Observasi dilakukan oleh guru kelas dibantu oleh 1 orang teman sejawat. Observasi dilakukan terhadap aktivitas siswa dan guru selama proses pembelajaran menulis cerita. Pengamatan dilakukan sesuai pedoman pengamatan peneliti.

Pada tahap ini, guru mengawali pelajaran dengan mengucapkan salam yang kemudian dijawab oleh semua siswa. Guru mengabsen siswa dengan menanyakan siswa yang tidak masuk. Selanjutnya guru memulai pembelajaran dengan menyampaikan tujuan yang ingin dicapai pada pembelajaran yang akan dilakukan. Tujuan yang ingin dicapai dalam pembelajaran ini adalah diharapkan siswa dapat menceritakan kembali isi cerita menggunakan kalimat sendiri secara runtut. Kemudian guru memberikan apersepsi pada siswa. Pada tahap ini yang dilakukan siswa adalah memperhatikan penjelasan guru dan menjawab pertanyaan guru.

b) Kegiatan Inti

Pada kegiatan inti, guru menjelaskan tentang materi menulis cerita, menyampaikan hal-hal yang harus diperhatikan dalam menulis cerita. Kemudian guru melakukan tanya jawab menegani materi yang baru saja dijelaskan. Pembelajaran dilanjutkan dengan membagi siswa menjadi 4 kelompok secara heterogen dengan masingmasing kelompok terdiri dari 4 siswa. Setiap siswa mengelompokkan diri dengan kelompok yang telah ditentukan oleh guru. Selanjutnya guru memberikan teks cerita berbentuk buku komik pada masing-masing kelompok. Setelah masingmasing kelompok memegang buku komik, guru meminta siswa untuk membaca buku komik dengan memahami isi cerita secara menyeluruh. Kemudian guru menjelaskan secara klasikal mengenai cara-cara menceritakan kembali isi cerita pada masing-masing kelompok. Masing-masing kelompok menulis cerita dengan diamati oleh observer dengan bantuan lembar observasi. Kemudian wakil kelompok mempresentasikan hasil kerja kelompoknya berupa menulis cerita yaitu dengan membacakan cerita yang telah ditulis.

c) Kegiatan Akhir

Pada tahap ini, guru menyuruh siswa untuk menulis cerita secara individu dengan menggunakan bahasanya sendiri, kemudian guru meminta siswa untuk mengumpulkan hasil pekerjaannya. Kemudian guru bersama siswa menyimpulkan materi dan merefleksi pembelajaran menulis cerita yang baru saja dilaksanakan. Kegiatan refleksi ini dilakukan dengan cara mengajukan pertanyaan mengenai pendapat siswa terhadap pembelajaran yang baru saja berlangsung. Pembelajaran diakhiri oleh guru dengan mengucapkan salam.

3) Observasi

Observasi dilakukan bersamaan dengan tindakan pembelajaran siklus I. Observasi proses dilakukan pada guru diperoleh hasil bahwa pada kegiatan awal, guru tidak 
memberikan motivasi dan mengaitkan pengalaman siswa dengan materi yang akan disampaikan. Hal ini berakibat siswa kurang bersemangat mengikuti pembelajaran dan kurang memahami materi yang akan diajarkan oleh guru. Pada kegiatan inti, guru sudah melaksanakan pembelajaran sesuai rencana pembelajaran. Pada kegiatan akhir, pembelajaran berjalan dengan baik dan sesuai dengan rencana pembelajaran. Kegiatan yang dilakukan guru bersama siswa membuat kesimpulan dan merefleksi pembelajaran yang telah dilakukan.

Penjelasan di atas menunjukkan bahwa guru sudah melaksanakan kegiatan dengan baik, namun masih ada aktivitas yang masih belum muncul, yaitu guru belum memberikan motivasi dan mengaitkan pengalaman siswa dengan pembelajaran yang akan disampaikan. Guru sudah terlihat menyampaikan meteri pembelajaran sesuai dengan rencana pelaksanaan pembelajaran yang telah disusun. Dalam menyampaikan materi yaitu menuis cerita dengan menggunakan media buku komik karya guru, guru sudah cukup baik dan dapat membangkitkan aktifitas dan minat siswa untuk mengikuti pembelajaran. Guru dapat membagi kelompok sesuai dengan kemampuan akademisnya walaupun dalam pembagiannya membuat siswa menjadi ramai, namun tidak menghambat pembelajaran yang berlangsung.

4) Refleksi

Kegiatan yang dilakukan pada tahap ini yaitu menganalisis, menjelaskan dan menyimpulkan hasil dari tes siswa dan hasil observasi.

a) Kemampuan Menulis Siswa Kelas III

Kemampuan menulis cerita siswa dalam pembelajaran bahasa Indonesia dengan menggunakan media buku komik pada siklus I diperoleh presentasi sebesar $75 \%$ atau kategori baik. Siklus II dilakukan merupakan usaha perbaikan dari siklus I. Usaha perbaikan yang dilakukan menyangkut perencanaan dan pelaksanaan tindakan yang belum sepenuhnya sempurna pada siklus I. terutama belum tuntasnya hasil belajar menulis cerita siswa kelas 3 SDN 2 Duwet. Langkah-langkah yang dilalui pada siklus II secara umum sama dengan langkah-langkah yang dilalui pada siklus I. Hal yang membedakannya adalah pada siklus II siswa dibentuk kelompok dengan teman satu bangku mereka serta buku komik yang digunakan alur ceritanya tidak terlalu panjang.

1) Perencanaan

Pada tahap ini yang dilakukan peneliti adalah :

a) Menyusun Rencana Pelaksanaan Pembelajaran perbaikan (RPP) Siklus II.

b) Mempersiapkan media berupa buku komik karya guru.

c) Menyusun lembar observasi aktivitas guru.

d) Menyusun pedoman penilaian Tes.

2) Pelaksanaan Perbaikan

Prosedur pembelajaran menulis cerita melalui penggunaan buku komik karya guru pada siklus ini dapat diuraikan sebagai berikut.

a) Kegiatan Awal

Pada tahap ini, guru mengawali pelajaran dengan mengucapkan salam yang kemudian dijawab oleh semua siswa. Guru mengabsen siswa dengan menanyakan siswa yang tidak masuk. Selanjutnya guru memulai pembelajaran dengan menyampaikan tujuan yang ingin dicapai pada pembeljaran yang akan dilakukan. Tujuan yang ingin dicapai 
dalam pembelajaran ini adalah diharapkan siswa dapat menceritakan kembali isi cerita menggunakan kalimat sendiri secara runtut. Kemudian guru memberikan motivasi kepada siswa dengan menyampaikan manfaat yang dapat diperoleh jika menguasai materi tentang menulis cerita. Hal ini dilakukan agar siswa lebih bersemangat mengikuti pembelajaran. Apersepsi juga disampaikan oleh guru kepada siswa. Pada tahap ini yang dilakukan siswa adalah memperhatikan penjelasan guru dan menjawab pertanyaan guru.

\section{b) Kegiatan inti}

Pada kegiatan inti, guru mengingatkan siswa pada materi menulis cerita pada pertemuan sebelumnya, membimbing siswa mengingat hal-hal yang perlu diperhatikan dalam menulis cerita. Pembelajaran dilanjutkan dengan membagi siswa menjadi 9 kelompok secara heterogen dengan masing-masing kelompok terdiri dari 2 siswa yaitu dengan teman satu bangku siswa. Setiap siswa mengelompokkan diri dengan teman satu kelompok. Selanjutnya guru memberikan teks cerita berbentuk buku komik karya guru pada masing-masing kelompok. Setelah masing-masing siswa memegang buku komik karya guru, guru meminta siswa untuk membaca buku komik karya guru dengan memahami isi cerita secara menyeluruh. Siswa merasa senang dan antusias mendapatkan buku komik karya guru dengan judul cerita yang baru dan alur ceritanya tidak terlalu panjang. Kemudian guru menjelaskan secara klasikal mengenai cara-cara menceritakan kembali isi cerita pada masing-masing kelompok. Kemudian wakil kelompok mempresentasikan hasil kerja kelompoknya yang berupa menulis cerita di depan kelas dengan bimbingan guru.

\section{c) Kegiatan Akhir}

Pada tahap ini, guru meminta siswa untuk menceritakan secara tertulis dengan bahasanya sendiri (tugas individu) kemudian mengumpulkan hasil pekerjaannya. Kemudian guru bersama siswa menyimpulkan materi dan merefleksi pembelajaran menulis cerita yang baru saja dilaksanakan. Kegiatan refleksi ini dilakukan dengan cara mengajukan pertanyaan mengenai pendapat siswa terhadap pembelajaran yang baru saja berlangsung. Pembelajaran diakhiri oleh guru dengan mengucapkan salam.

\section{3) Observasi}

Pelaksanaan pembelajaran pada kegiatan awal, kegiatan inti, dan kegiatan akhir berjalan dengan baik dan sesuai dengan rencana pembelajaran. Guru sudah memberikan motivasi dan menghubungkan pengalaman siswa dengan materi yang akan disampaikan. Pada kegiatan menulis cerita, siswa dibentuk kelompok dengan teman satu bangku mereka. Hal ini dilakukan agar siswa tidak ramai dan bergurau. Guru sudah mengganti buku komik karya guru dengan judul lain dan alur ceritanya tidak terlalu panjang, sehingga siswa tidak merasa bosan dan mampu memahami isi cerita secara menyeluruh. Dengan demikian, dapat disimpulkan tindakan pembelajaran sudah cukup maksimal.

Berdasarkan observasi proses siklus II, dapat dilihat bahwa guru dan siswa sudah melaksanakan kegiatan sesuai dengan rencana pembelajaran yang telah dibuat. Hal ini ditandai dengan munculnya semua aktivitas yang diinginkan. Dengan demikian, proses pembelajaran sudah dilakukan secara maksimal. 
4) Refleksi

Refleksi dilakukan oleh peneliti dan guru kelas III setelah proses pembelajaran. Hal yang dilakukan pada tahap ini yaitu menganalisis, menjelaskan dan menyimpulkan hasil dari observasi dan hasil tes siswa, yang hasilnya sebagi berikut. Kemampuan Menulis Siswa Kelas III. Kemampuan menulis cerita siswa dalam pembelajaran bahasa Indonesia dengan menggunakan media buku komik pada siklus II diperoleh presentasi sebesar $85 \%$ atau kategori baik.

\section{KESIMPULAN}

Pada kegiatan penelitian diperoleh hasil Pada siklus I tingkat keberhasilan yang dicapai dapat dilihat dari hasil kemampuan siswa dalam menulis cerita. Sebelumnya pada saat prasiklus jumlah siswa yang mengalami ketuntasan belajar hanya 6 siswa (30\%), karena pada tahap ini guru belum memberikan tindakan pada pembelajaran menulis cerita. Setelah diberi tindakan yaitu dengan penggunaan media buku komik dalam pembelajaran menulis cerita siswa yang mengalami ketuntasan belajar meningkat menjadi 15 siswa (85\%). Akan tetapi hal ini belum mencapai target yang diharapkan, karena siswa masih kurang mengembangkan idenya sehingga cerita yang ditulis siswa sebagian besar masih dipengaruhi oleh temannya dan kurang panjang. Untuk memperbaiki pembelajaran pada siklus I maka peneliti melaksanakan siklus II, dimana kekurangan-kekurangan yang terjadi pada siklus I disempurnakan dan diperbaiki pada siklus II. Dalam hal ini peneliti dan guru berkolaborasi untuk memperbaiki kekurangakekurangan pada siklus I tersebut. Pada siklus I alur cerita pada media buku komik karya guru yang digunakan terlalu panjang sehingga siswa kesulitan mengembangkan idenya. Setelah diadakan perbaikan maka pada siklus II buku komik karya guru yang digunakan ceritanya tidak terlalu panjang dan kata-katanya mudah dimengerti oleh siswa sehingga siswa dapat menceritakan kembali isi cerita secara runtut. Pada siklus II setelah diberi tindakan perbaikan maka kemampuan menulis cerita siswa pada siklus II meningkat menjadi 16 siswa (90\%). Pada siklus II ini ketuntasan belajar siswa sudah mencapai kriteria ketuntasan minimal yang telah ditentukan.

\section{DAFTAR RUJUKAN}

Akhadiah, S. 1997. Pembinaan Kemampuan Menulis. Jakarta: Erlangga

Arsyad, A. 2006. Media Pembelajaran. Jakarta: Raja Grafindo Persada.

Danim, S. 1994. Media Komunikasi Pendidikan. Jakarta: Bumi Aksara.

Franz, K. 1983. Komik Sebagai Media Pembelajaran. Jakarta: Remaja karya. Hamalik, O., 1980. Media Pendidikan. Bandung : Alumni

Keraf, G. 1987. Argumentasi dan Narasi. Jakarta: Gramedia Puataka Utama. 
Nurgiyantoro, B. 2009. Penilaian dalam Pengajaran Bahasa dan Sastra Edisi Ketiga . Yogyakarta: BPEF.

Parera. J. D. 1984. Belajar Mengemukakan Pendapat. Jakarta: Erlangga.

Purwanto M. N., 2001. Prinsip-Prinsip dan Teknik Evaluasi Pengajaran. Bandung: PT Remaja Rosdakarya.

Rohani, A., 1997. Media Intruksional Edukatif. Jakarta: PT Rineka Cipta.

Sadiman A. S, R. Rahardjo, A. Haryono dan Rahardjito., 1996. Media Pendidikan, Pengertian, Pengembangan, dan Pemanfaatannya. Jakarta: Pustekkom Dikbud dan PT Raja Grafindo Persada.

Soetomo, 1993., Dasar-dasar Interaksi Belajar Mengajar. Surabaya: Usaha Nasional

Suriamiharja, A., dkk. (1996/1997). Petunjuk Praktis Penulis. Jakarta: Depdikbud

Tarigan, H. G. 1986. Menulis sebagai suatu Keterampilan Berbahasa. Bandung: Angkasa

Tarigan, H. G. 2008. Menulis. Bandung: Angkasa

Wardani, I. G. A. K. 2003. Penelitian Tindakan Kelas. Jakarta: Pusat Penerbitan UT.

Wiyanto, A. 2008. Menulis dan mengarang samakah? . Jakarta : Asosisasi Guru Bahasa Indonesia-Jepang

Wiyatmi. 2006 . Pengantar Kajian Sastra . Yogyakarta: Pustaka. 
Volume 3, Nomor 2, Agustus 2019 